UDC 341

\title{
THE ROLE OF EUROPEAN COMMISSION IN KEEPING STATE AID LEGISLATION UP-TO-DATE: RATIONALE, BUSINESS PROCESSES, PRACTICAL IMPLEMENTATION

\author{
РОЛЬ ЄВРОПЕЙСЬКОЇ КОМІСІЇ В АКТУАЛІЗАЦІЇ НОРМАТИВНО-ПРАВОВОЇ БАЗИ \\ ЩОДО ДЕРЖАВНОЇ ДОПОМОГИ: ПЕРЕДУМОВИ, \\ БІЗНЕС-ПРОЦЕСИ, ПРАКТИЧНА РЕАЛІЗАЦІЯ
}

\author{
Fokina N.V., $2^{\text {nd }}$ year Ph.D student \\ Institute of International Relations of Taras Shevchenko National University of Kyiv
}

\begin{abstract}
The article is dedicated to the multidimensional and currently relevant issue in Ukraine that has to do with the peculiarities of law-making process and standard operating procedures in the field of amending and updating the regulatory framework for state aid and increasing the efficiency thereof. In the European Union, the institute of state aid to undertakings has been operational for more than 60 years. This legal institute plays a pivotal role in controlling government expenditures aimed at supporting businesses, regardless of their status, nature, name or form of ownership. The European Commission has been entrusted with a task to support arranging the preparatory work in course of the law-making process.

Of particular relevance is the study of standard operating procedures in the European Union, which are aimed at rational lawmaking, i.e., drafting and updating regulatory framework based on monitoring organized and carried out by the European Commission via collecting information from stakeholders involved in state aid. This article examines the mechanisms and tools used by the European Commission to ensure fitness check of the legal framework in the area of state aid and to amend it on the basis of an evidence-based approach.

For Ukraine, the issue of law-making in the field of state aid is becoming increasingly important given the fact that the institute of state aid in Ukraine was established on the basis of the EU acquis and must comply with the acquis. One of the most comprehensive and far-reaching competition provisions set forth in international trade agreements can be found in 2014 Association Agreement between Ukraine and the EU. In particular, Ukraine is to establish a format of state aid control similar to the one used in the EU, where there is a link between competition and market access. The article aims to highlight best practices of the European Union which can be adapted to the legal lay of the land in Ukraine given the fact that the regulatory framework on state aid to undertakings will need changes and clarifications, and the effective drafting and implementation thereof will contribute to the overall efficiency of state aid.
\end{abstract}

Key words: state aid to undertakings, monitoring of the legal framework, best practices of the European Commission, fitness check, modernization of state aid, evidence-based approach.

Стаття присвячена багатовимірному та актуальному нині в Україні питанню щодо особливостей правотворчого процесу та стандартних операційних процедур у галузі актуалізації та збільшення ефективності нормативно-правової бази про державну допомогу. У Європейському Союзі вже протягом понад 60 років функціонує інститут державної допомоги суб'єктам господарювання. Цей правовий інститут відіграє ключову роль у контролі за державними видатками, спрямованими на підтримку суб'єктів господарювання незалежно від їх статусу, природи, назви чи фрорми власності. Європейська комісія відіграє суттєву роль в організації підготовчої роботи під час правотворчого процесу.

Особливо актуальним є дослідження стандартних операційних процедур в Європейському Союзі, які спрямовані на раціональну правотворчість, тобто розробку та актуалізацію нормативно-правових актів на основі моніторингу, який організовує та здійснює Європейська комісія шляхом збирання інформації від суб'єктів, залучених до реалізації норм державної допомоги. Ця стаття присвячена дослідженню механізмів та інструментів, які застосовує Європейська комісія з метою перевірки актуальності нормативно-правової бази державної допомоги та внесення змін до неї на основі підходу, заснованого на доказах.

Для України питання правотворчості у галузі державної допомоги набуває все більшої актуальності з огляду на те, що інститут державної допомоги в Україні започаткований на основі acquis $€ C$ та має відповідати acquis. Прикладом одних із найбільш комплексних положень про конкуренцію, які містяться в торговельних угодах, є Угода про асоціацію між Україною та ЄС 2014 року. Зокрема, Україна повинна встановити форму контролю державної допомоги, подібну до моделі, яка використовується в ЄС, де існує зв'язок між поняттями конкуренції та доступу до ринку. Стаття спрямована на висвітлення кращих практик Європейського Союзу, які можуть бути адаптованими до правових реалій України, адже законодавство про державну допомогу суб'єктам господарювання буде потребувати змін та уточнень, а ефрективна їх розробка та застосування сприятиме ефективності інституту державної допомоги в цілому.

Ключові слова: державна допомога суб'єктам господарювання, моніторинг нормативно-правової бази, передовий досвід Європейської комісії, перевірка актуальності, модернізація державної допомоги, підхід на основі фрактів.

Formulation of the problem. It has been proven that there exist numerous advantages of state aid regulation. First and foremost, state aid is aimed at facilitating the broad promotion of a market economy and rationalization of industrial and investment policy. This is done by preventing unfair allocation of state resources to undertakings that would harm competition and hinder economic process. Therefore, researching the ways to ensure relevant and actionable regulatory framework is essential as such regulatory framework strongly supports preventing the inefficiency of state aid and does not allow state aid grantors to simply 'keep their beneficiaries afloat' when it does not yield any economic benefit in the longer run.

Analysis of the research. The issues of state aid modernization, efficacy of enforcing state aid rules and implementation of block exemptions have been researched by Angela Wigger, Erika Szyszczak, Hubert Buch-Hansen, Leigh Hancher, Phedon Nicolaides, Piet Jan Slot, Tom Ottervanger and others.

Formulation of the purpose of the article. This article is aimed at uncovering the standard operating procedures for state aid modernization via examining the methods and tools utilized by the European Commission to support evidencebased lawmaking.

Presenting main material. The effect state aid instruments have on economic growth, investment climate and budgetary discipline in EU member states has been the subject-matter of numerous pieces of research. The results of such research differ: mostly, there can be observed a positive influence of state aid on economic development, there can be traced improvement in the investment climate [1], but there may be found some research results that claim that state aid is not that effective in facilitating economic development and investment attractiveness [2].

Still, at the EU level state aid has proven to be an effective institute contributing to providing supervision over supporting business at all levels of government when it is evident that such support would trigger positive developments in the economy or when the activity that an undertaking is carrying out is considered to be a market failure. Furthermore, state aid rules help avoid duplication and irrational use of state resources, 
which contributes to budgetary discipline as a whole and makes undertakings properly plan and implement their financial activities. In a broader perspective, any involvement of the government with a view to providing support or assistance to a business or group of businesses will constitute a subsidy. Researchers such as W. Fickentscher, S. Quigley, call such an involvement an intervention [3]. Therefore, proper enforcement of state aid rules is also known to shape new approaches to modernization of industrial production, ensuring steady and positive economic development on a large, medium and small scale as well as taking steps towards attracting foreign direct investments. Therefore, properly drafted and enforced state aid rules trigger best practices in undertakings' budgetary discipline and economic development.

Therefore, European Union finds it essential to keep regulatory framework up to date, relevant and actionable. Not only European Parliament plays an important role here, but the European Commission as well. Within a bigger project called state aid modernization, the European Commission has been entrusted with gathering inputs from stakeholders engaged in state aid rules enforcement with a view to support the law-making bodies in their efforts aimed at ensuing proper quality of the regulatory framework governing state aid.

Some researchers [4] deem that the first and foremost objective of and rationale behind EU state aid policy is impacted by the forming of a common (internal) market and at the same time the supporting role of state aid rules for the four freedoms. Therefore, ensuring proper support for drawing up regulatory framework to govern respective legal and economic realm is put as an action for the Directorate General for Competition within the European Commission. Fiscal discipline and economic efficiency are considered to be one of the core values in law-making as regards state aid rules. According to Kelyn Bacon, "State aid policy is an eclectic mix of internal market (trade) policy, competition rules and considerations of economic efficiency and fiscal discipline [5, p. 5]. Similar views are advocated in Ukrainian legal and scientific community. The basis for drafting state aid legislation is predicated on the need to "prevent inappropriate interference by public authorities and local governments in the functioning of a market mechanism based on competition by providing resources to one or more commercial enterprises" [6, p. 323]. Therefore, it is crucial to explore the steps taken by the European Commission to ensure the required support in analyzing data pertaining to state aid rules enforcement so that this data can become the basis for evidence-based approach in amending and modifying state aid rules.

The European Commission has been to a great extent active in arranging the procedure known as 'fitness check'. This procedure is aimed at monitoring the regulatory framework in respect of state aid, finding out what provisions should be amended and modified. This procedure was started within a bigger effort - the state aid modernization package. One of the outputs produced within this procedure is annual State Aid Scoreboard report. The latest State Aid Scoreboard report 2020 [7] was published in June 2021 and covers data over 2019. The latest analytics contained in State Aid Scoreboard 2020 Report suggest that in 2019, EU Member States spent on State aid EUR 134.6 billion, which makes up $0.81 \%$ of the overall GDP in contrast to $€ 116.2$ billion corresponding to $0.76 \%$ of EU GDP in 2017 and $€ 106.6$ billion, i.e. $0.72 \%$ of EU GDP, in 2016. In 2018, the share of GDP spent on state aid was relatively the same as in 2019. Direct grants have still by far proved to be the most frequently reported to state aid instrument in 2019 , constituting $62.8 \%$ of the total expenditure. Approximately $51 \%$ of the overall amount of funds allocated was targeted at State aid dedicated to environmental and energy savings. The rationale behind such figures is that development and implementation of numerous renewable energy initiatives in many Member States is carried out extensively. Horizontal objectives of common interest are the ones at which state aid is heavily targeted. These objectives encompass environmental protection mentioned above, research, development and innovation, as well as regional development.

Therefore, the conclusion as to these figures and developments are that the amount spent on state aid compared to previous period increased. However, the target undertakings state aid recipients were not undertakings in highly difficult financial situation, but rather undertakings whose activity can give tangible benefits to individuals and businesses. They were granted the funds according to strategic planning of the respective member states.

State aid control does not hinder Member State governments from making the target of aid on their own legitimate policy objectives and priorities. The vast majority of Member States have determined environmental protection and energy savings as their most primary policy objectives to be pursued. These 'green objectives' are then followed mostly by regional development, research, development and innovation, as well as culture. Hence, it has been shown that Member States can exercise their sovereignty in internal development policy as to the choice of recipient of state aid provided that EU law on state aid and acquis are not violated.

Since 2015, there have been witnessed decentralization trends in state aid rules enforcement. Thus, over $96 \%$ of reported new state aid measures have been processed under the General Block Exemption Regulation procedure. This number has significantly increased by approximately 28p.p. as opposed to the figures for 2013. This development is in line with the Commission's approach to be 'big on big things and small on small things' - to focus on delivering more and faster, while doing less where it is perceived not to have an added value.

This development is of very critical importance for strategic governance in terms of state aid procedures. Here the European Commission clearly draws distinction between minor cases that do not constitute much trade distortion for Member States and really important cases that can largely impact economy of a Member State, the internal market and competition in the EU. This is a best practice which can be used in terms of providing regulatory, institutional and enforcement framework of the functioning of state aid institute.

In course of this report, the benefits of the State Aid Modernization were confirmed. It was found that there Member States implemented public support in a more speedy manner, to the benefit of citizens, businesses and regions; there was less bureaucracy, red tape and delays. The role of State aid control was also highlighted in steering public aid towards objectives of common interest (e.g. R\&D\&I and investment in renewable energy), while ensuring benefits for society and minimising the negative impact of State aid on competition.

The European Commission adopted another instrument - Communication on investing in smart, innovative and sustainable industry in 2017. Another programme instrument that came into play is renewed EU Industrial Policy Strategy [9]. It is stated there that EU and Member States' funds should be mobilized as incentives to create added value in the economy without jeopardizing the development of an active private market for project financing. The Union guarantees that state aid properly encourages firms to invest in research and development - including the ability to match aid received from non-EU competitors for similar projects and other competitiveness measures, and that individual companies are not granted economic benefits that adversely affect competition and trade between Member States.

In the Commission Working Staff Document on the Implementation of the Circular Economy Action Plan the role of state aid is also noted in implementing the Action Plan item "Innovation, Investments and Other Horizontal Measures". It is demonstrated therein that there is a need 
for focused state aid seminars. This is intended to broaden understanding of implementing state aid rules in practice and to share knowledge needed for assisting Member States in their efforts for growth and development because state aid is aimed at undertakings that may develop innovations and it is not intended for non-market mode of undertakings.

The European Commission has certain operating procedures it works under to achieve the objectives of ensuring evidence-based approach for lawmaking. Whenever the need arises, the European Commission is entrusted with submitting, observing procedural regulations, a legislative proposal to the Council of the EU and the European Parliament with a view to extending the respective rules and regulations pertaining to state aid. Thus, such a proposal has been put forward in respect of 7 documents in the EU till 2022. The European Commission further continues to evaluate provisions thereof with a view to further possible making them even more relevant.

Furthermore, "fitness check" procedure is also relevant and applicable to 2008 Railways Guidelines. Moreover, 2012S Short term export credit Communication also falls under the "fitness check" procedure. The rules contained in the instruments highlighted above were not subject to revision within the framework of the State Aid Modernisation package, yet as of today it has remained quite relevant to evaluate them against the "fitness check" procedure in view of the fact that there arose novel developments in EU law as well as the Commission's case practice.

Conclusions. Seeing the benefit and efficiency of the reform within state aid modernization package that is predicated upon evidence-based approach, the European Commission continues to analyze its results. However, the results of the reform have only recently started to manifest and not all rules have been reformed to check whether the rules have actually worked in accordance with the intention behind them and whether are fit for their purpose. This is done with a view to developing a policy after most instruments adopted for a certain time period are be due to expire. Another aspect to be paid proper heed to is the fact that certain state aid rules that were concluded within the framework of modernisation processes and procedures do not have a clearly fixed expiry date. To make sure that predictability and legal certainty is properly provided and complied with in the course of preparation for any further possible updates in the future in respect of State aid rules that were put in operation as the constituents of the state aid modernization package, the Commission may prolong the validity of those State aid rules, which would otherwise have expired before new instruments have been drafted.

An important factor is that there is an established process for fitness check and evaluation. The fitness check procedure is mostly effected pursuant to the Better Regulation Guidelines. These guidelines provide practical recommendations as to, in particular, how to apply general principles of better regulation, carry out impact assessments, determine impacts, prepare proposals, how to do implementation and transposition, what is the way for monitoring the application of an intervention, how to carry out evaluations and fitness checks, consult stakeholders, apply methods, models, costs and benefits. Better regulation portal is the platform on which progress of fitness check and evaluation can be traced.

The fitness check procedure implemented by the European Commission may be adapted and adjusted to the legal lay of the land in Ukraine. The Antimonopoly Committee of Ukraine may want to draw inspiration from the best practices employed by the European Commission in order to support the Parliament of Ukraine and other stakeholders in drafting state aid regulatory framework by introducing monitoring tools that would pinpoint the best practices and scope for improvement so that state aid rules enforcement contribute to budgetary discipline and economic efficiency.

\section{REFERENCES}

1. Commission sets out state-aid overhaul to drive growth. EU Observer. URL: https://euobserver.com/economic/116194 (access date: 10 January 2021).

2. Çiğdem B.T., Fidrmuc J. State Aid Policy in the European Union. Journal of Market States. 2015. Vol. 53. № 5. P. 1143-1162. DOI: 10.1111/jcms.12247.

3. Quigley C. European State Aid Law and Policy: Second Edition. Hart Publishing, 2009. 574 p.

4. Papp M. EU State Aid Law and National Public Policy Choices URL: https://hpops.tk.mta.hu /uploads/files/Papp.pdf (access date: 12 January 2021).

5. Bacon K. European Union Law of State Aid. Oxford University Press. 2013.

6. Smyrnova K.V. Legal regulation of competition in the European Union: Theory and Practice : Monograph. 2nd ed., Odessa, Phoenix 2017. 490 p.

7. State Aid Scoreboard 2021. The European Commission website. URL: https://ec.europa.eu/competition-policy/system/files/2021-06/ state_aid_scoreboard_note_2020.pdf (access date: 17 January 2021).

8. State Aid Scoreboard 2018. The European Commission website. URL: https://ec.europa.eu/competition/state_aid/scoreboard/state_aid_ scoreboard_2018.pdf (access date: 17 January 2021).

9. Communication from the Commission to the European parliament, the European Council, the Council, the European Economic and Social Committee, the Committee of the Regions and the European Investment Bank. Investing in a smart, innovative and sustainable industry : A renewed EU Industrial Policy Strategy (COM/2017/0479 final). The European Commission website. URL: https://eur-lex.europa.eu/legal-content/ EN/TXT/?uri=CELEX\%3A52017DC0479 (access date: 17 January 2021).

10. Commission staff working document accompanying the document report from the Commission to the European Parliament, the Council, the European Economic and Social Committee and the Committee of the Regions on the implementation of the Circular Economy Action Plan. The European Commission website. URL: http://ec.europa.eu/environment/circular-economy/pdf/report_implementation_54_actions.pdf (access date: 17 January 2021). 